Изв. АН Эстонии. Геол., 1990, 39, № 4, 133-141

УДК $553.985+553.982(474.2)$

Велло КАТТАЙ

\title{
О СОСТАВЕ ПРИРОДНЫХ БИТУМОВ ЭСТОНИИ
}

Вопросы о закономерностях распространения в пределах Эстонии локальных скоплений природных битумов (ПБ) по стратиграфическому разрезу, территориальному расположению, фазовому состоянию, особенностям морфологии и условиям залегания уже рассматривались (Каттай, Кала и др., 1990). Выделены два типа битумопроявлений. Один из них - послойные плоские линзы («лепешки») твердых битумов. Они отмечены в отложениях от лонтоваского горизонта нижнего кембрия $\left(\epsilon_{1} l n\right)$ до кукрузеского горизонта среднего ордовика $\left(\mathrm{O}_{2} k k\right)$ в Северо-Восточной Эстонии. В последнем, а конкретно - в разрабатываемой промышленной пачке кукерситов Әстонского месторождения, вскрыто наибольшее количество ПБ (Кogeгman, 1933; Люткевич, Курбатская, 1964; Каттай, Кундель, 1987; Клубов, Уров, 1988; и др.).

Другой тип битумопроявлений развит преимущественно в Западной Әстонии, на островах Сааремаа и Хийумаа, с общей тенденцией увеличения количества находок в северо-западном направлении. По фазовому состоянию эти ПБ подразделяются на жидкие нефтеподобные, густые вязкие (преобладают) и твердые. Формы проявления их различны. В возрастном отношении битумы зафиксированы в разрезе от кундаского горизонта $\left(\mathrm{O}_{1} k n\right)$ нижнего ордовика до паадлаского $\left(\mathrm{S}_{2} p d\right)$ верхнего силура. Максимальные скопления их приходятся на породы среднего и верхнего ордовика в районе Кярдлаской кратерообразной структуры на о-ве Хийумаа (Каттай, Клубов и др., 1990).

$\mathrm{K}$ настоящему времени известно свыше 110 пунктов битумопроявлений, из них изучено 26 (рис. 1). В некоторых точках отобраны пробы. и проведены исследования ПБ из разных стратиграфических уровней нли выполнены параллельные анализы по одним и тем же пробам в разные годы различными исследователями. Таким образом, имеются лабораторные данные в целом по 35 пробам ПБ (табл. 1, 2). Распределение их по стратиграфическим горизонтам следующее: лонтоваский $\left(\mathrm{E}_{1} \ln \right)-1$, латорпский $\left(\mathrm{O}_{1} l t\right)-2$, кундаский $\left(\mathrm{O}_{1} k n\right)-2$, ласнамягиский $\left(\mathrm{O}_{2} l s\right)-2$, кукрузеский $\left(\mathrm{O}_{2} k k\right)-12$, идавереский $\left(\mathrm{O}_{2}\right.$ id $)-4$, кейлаский $\left(\mathrm{O}_{2} k l\right)-3$, оандуский $\left(\mathrm{O}_{2}\right.$ on $)-1$, раквереский $\left(\mathrm{O}_{2} r k\right)-1$, вормсиский $\left(\mathrm{O}_{3}\right.$ vr $)-2$, райккюлаский $\left(\mathrm{S}_{1} r k\right)-4$, яагарахуский $\left(\mathrm{S}_{1} j g\right)$ -1 .

Твердое углеподобное вещество битумных «лепешек» Северо-Восточной Әстонии довольно однородно по составу и свойствам. Его зольность не превышает $6 \%$, растворимость в хлороформе более $93 \%$. Элементный состав: $\mathrm{C}-84,6-88,8 \%, \mathrm{H}-8,7-9,5 \%, \mathrm{~N}-0,7-1,7 \%, \mathrm{O}-1,5-$ $4,3 \%, \mathrm{~S}-$ в основном до $2 \%$, отношение $\mathrm{C} / \mathrm{H}-9,5-10$, атомное $\mathrm{H} / \mathrm{C}$ преимущественно $1,2-1,25$ (табл. 2). Некоторое исключение по содержанию C $(81,6 \%)$, отношению $\mathrm{C} / \mathrm{H}$ и $\mathrm{H} / \mathrm{C}$ представляет 1-я проба из кембрийских глин, исследованная в начале века (Kogerman, 1933). Ocoбого доверия к ней нет.

Групповой состав этих битумов (табл. 3) харғацениуется преобла-

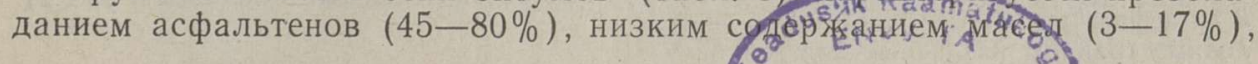

(C) Eesti TA Toimetised, Geoloogia, 1990 
высоким содержанием смол $(20-45 \%)$. Согласно существующим классификационным схемам ПБ, рассматриваемые твердые битумы («лепешки») по их поведению в органических растворителях, элементному и групповому составам могут быть отнесены к классу асфальтитов (табл. 4 ; рис. 2,3$)$.

ПБ (жидкие, вязкие и твердые разности) в западных районах и на островах Эстонии редко образуют высококонцентрированные скопления, чаще они наблюдаются в виде пятен пропитки породы от желтоватьго до черного цвета; капель-выпотов, заполнений мелких каверн, пор; прима-

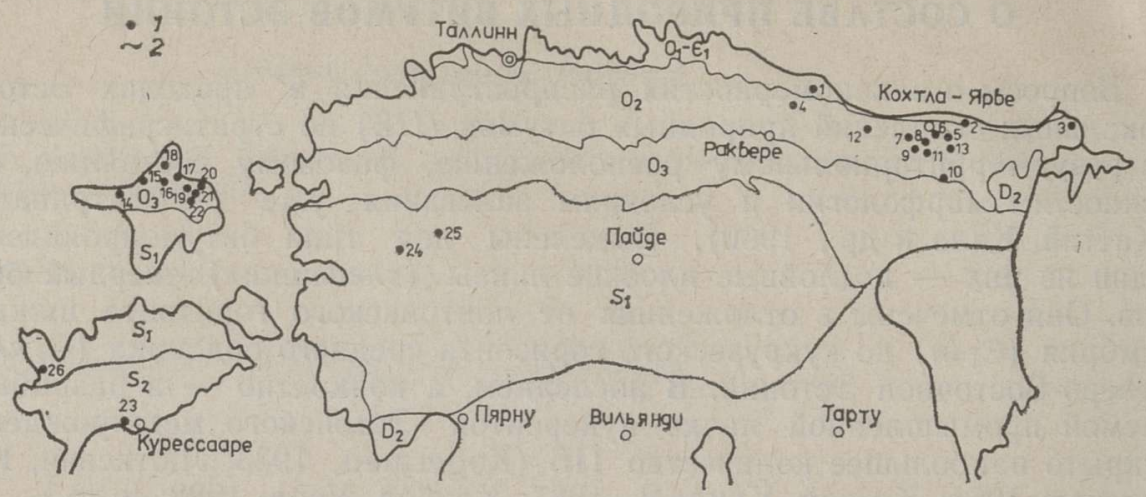

Рис. 1. Схема расположения изученных пунктов битумопроявлений: 1 - битумопроявления, их номера, 2 - границы стратиграфических подразделений. Перечень пунктов (кар. - карьер, обн. - обнажение, ш. - шахта, скв. - скважина): 1 - кар. Кунда $\left(E_{1} l n\right), 2$ - обн. Тойла $\left(\mathrm{O}_{1} l t\right), 3-$ обн. Нарва $\left(\mathrm{O}_{1} k n\right), 4-$ кар. Ару $\left(\mathrm{O}_{2} l s\right), 5-$ ш. Кукрузе $\left(\mathrm{O}_{2} k k\right), 6$ - ш. Кява $\left(\mathrm{O}_{2} k k\right), 7$ - ш. Кохтла $\left(\mathrm{O}_{2} k k\right), 8$ - ш. № $4\left(\mathrm{O}_{2} k k\right)$, 9 - ш. Сомпа $\left(\mathrm{O}_{2} k k\right), 10$ - ш. Әстония $\left(\mathrm{O}_{2} k k\right), 11-$ ш. Виру $\left(\mathrm{O}_{2} k k\right), 12$ - ш. Кивиыли $\left(\mathrm{O}_{2} k k\right), 13$ - ш. Таммику $\left(\mathrm{O}_{2} k k\right), 14$ - скв. Луйдья $\left(\mathrm{O}_{1} k n, \mathrm{O}_{2} l s, \mathrm{O}_{2} k k\right), 15$ - скв. Кыргессаape $\left(\mathrm{O}_{2} k k, \mathrm{O}_{2} i d, \mathrm{O}_{2} \mathrm{On}\right), 16$ - скв. Кидасте $\left(\mathrm{O}_{2} i d, \mathrm{O}_{2} k l\right), 17$ - скв. Таресте $\left(\mathrm{O}_{2} i d\right), 18$ - скв. Каусте $\left(\mathrm{O}_{2} i d\right), 19$ - скв. Кярдла $\left(\mathrm{O}_{2} k l, \mathrm{O}_{2} r k\right), 20$ - скв. Хийессааре $\left(\mathrm{O}_{2} k l\right), 21$ - обн. Палукюла $\left(\mathrm{O}_{3} v r\right), 22$ - скв. Паладе $\left(\mathrm{O}_{3} v r\right), 23$ - скв. Кингисеппа $\left(\mathrm{S}_{1} r k\right), 24$ - обн. Кулламаа $\left(\mathrm{S}_{1} r k\right), 25$ - обн. Ванакюла $\left(\mathrm{S}_{1} r k\right), 26$ - обн. Яагараху

$\left(S_{1} j g\right)$. В. скобках указаны горизонты, из которых отобраны пробы битумов.

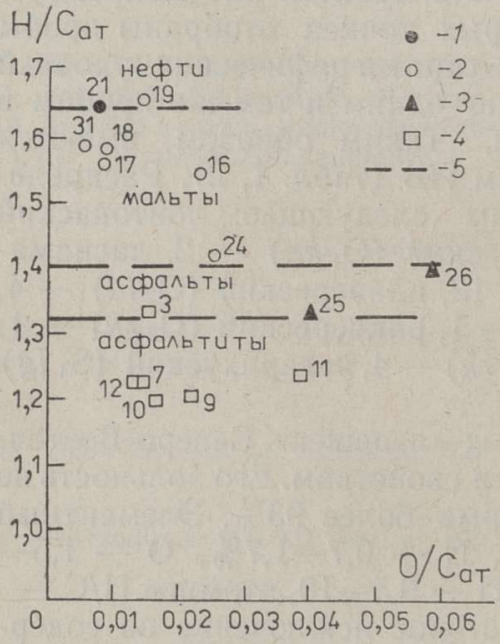

Рнс. 2. Расположение природных битумов Эстонии на диаграмме атомных отношений $\mathrm{H} / \mathrm{C}-\mathrm{O} / \mathrm{C}$ элементного состава (цифры номера проб): 1 - нефти, 2 - мальты, 3 - асфальты, 4 - асфальтиты, 5- условные границы различных классов биту-

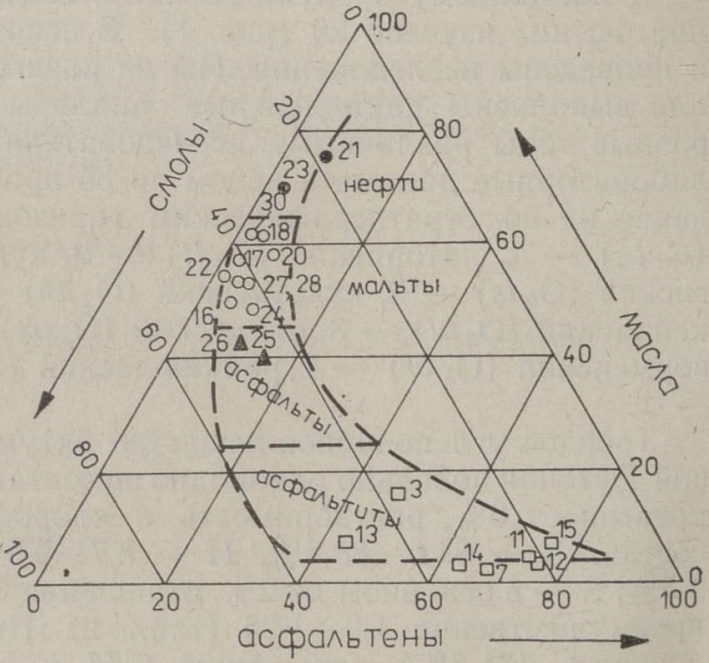

Рис. 3. Расположение природных битумов Эстонии на тригонограмме группового состава: масла-смолы-асфальтены (условные обозначения см. в подписи к рис. 2). 
वै

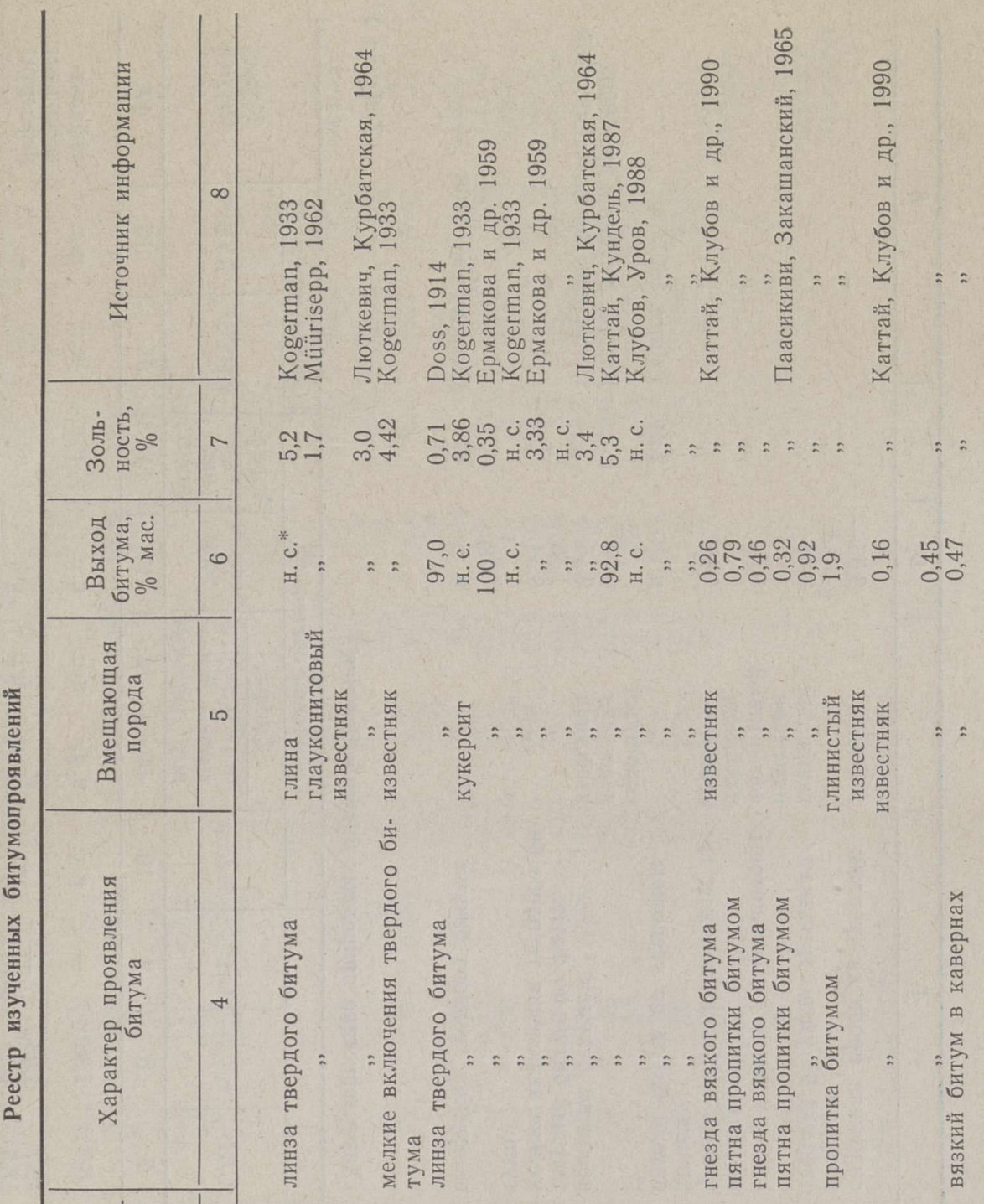

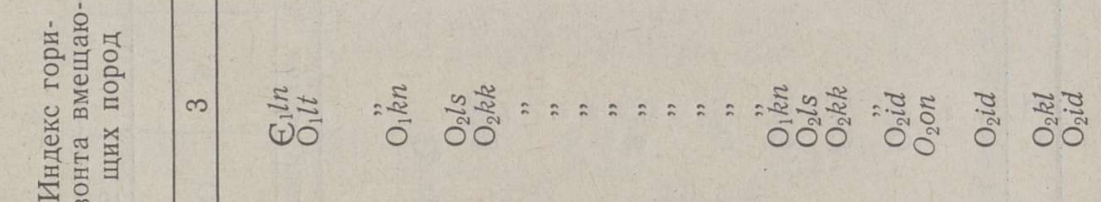

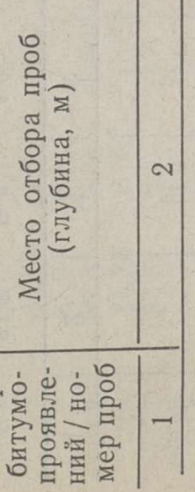

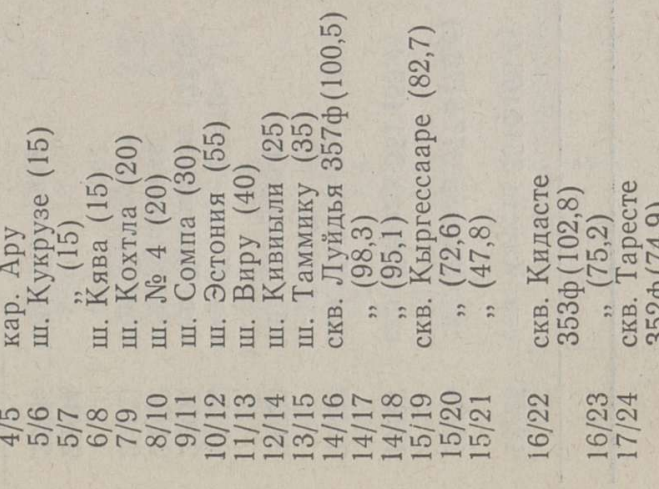




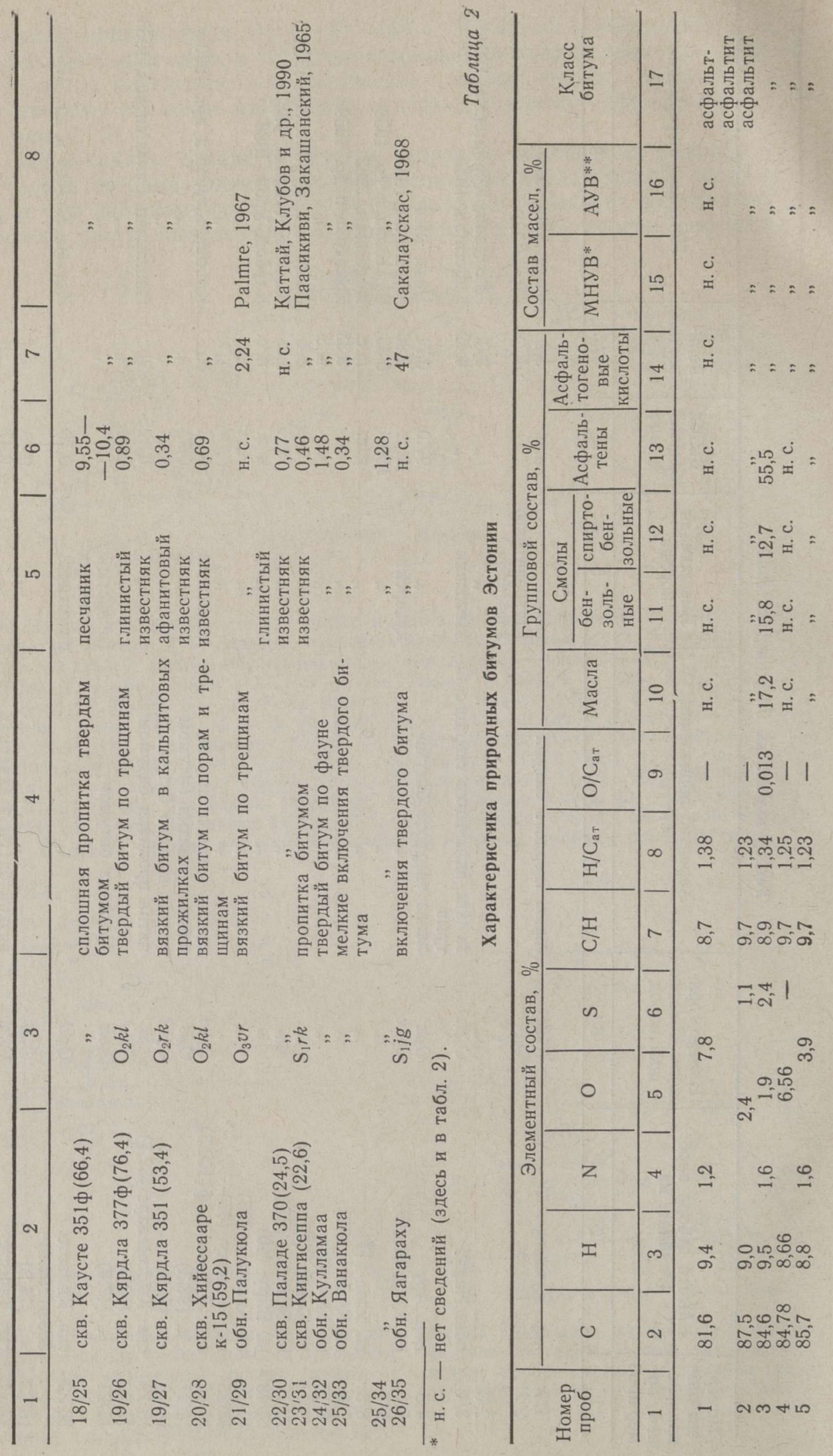




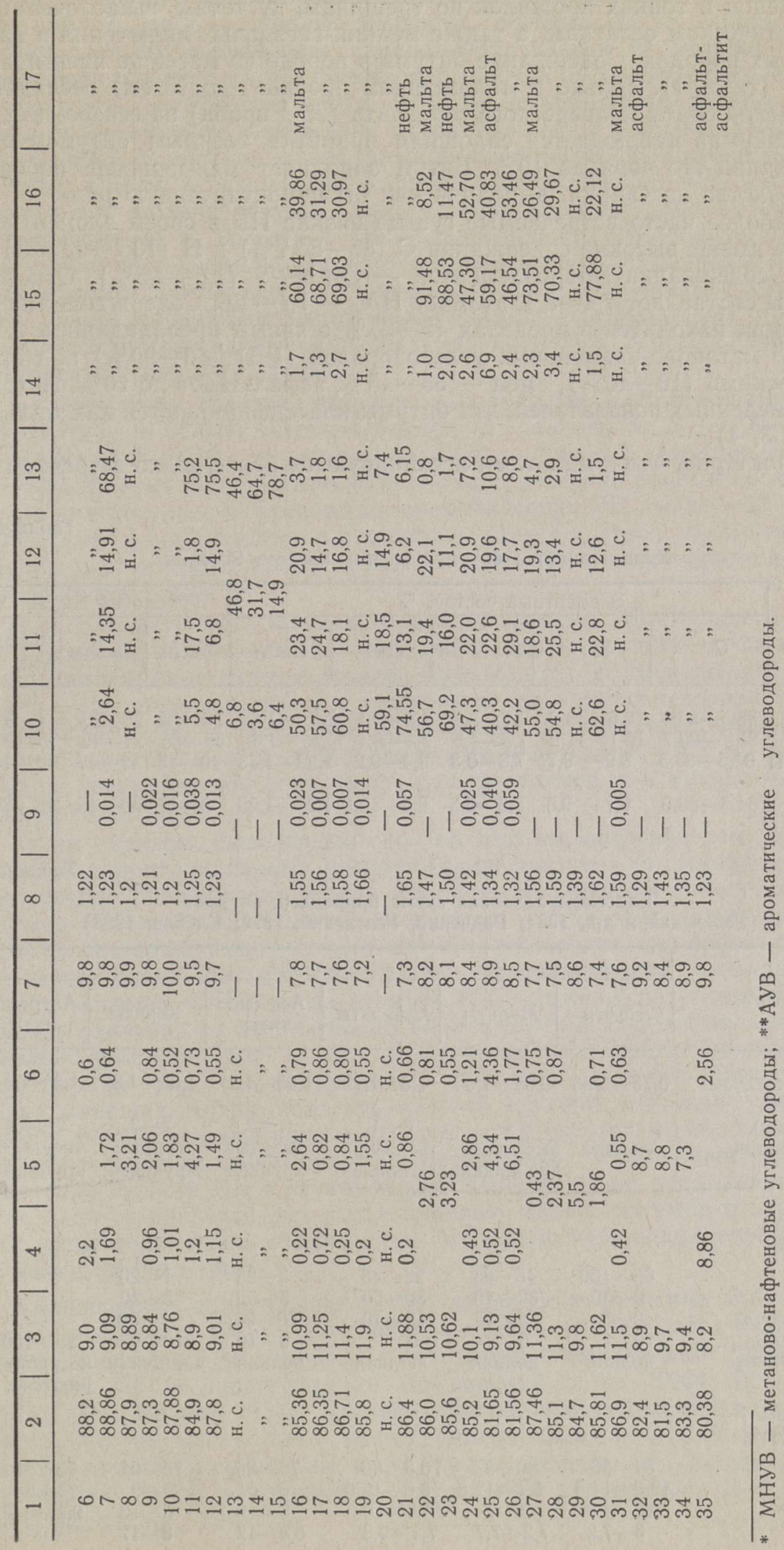


зок, пленок и тонких прожилок по трещинам, пустотам, выщелоченным фаунистическим остаткам, а также мелких гнездовых включений в карбонатных породах. Содержание битума в породе по массе не превышает $1-2 \%$ (табл. 1). Только в маломощном прослое (до 15 см) песчаника кярдлаской свиты идавереского горизонта (25-я проба) на северо-западе о-ва Хийумаа наблюдается сплошная пропитка твердым битумом при содержании его порядка $10 \%$. Битум заполняет межзерновое поровое пространство песчаника, выполняя как бы цементирующую роль.

Наиболее часто встречаемые густые вязкие ПБ в своем элементном составе имеют высокие содержания С $(85-86,7 \%)$ и Н $(10,1-11,5 \%)$ и низкие содержания гетероэлементов - $\mathrm{O}+\mathrm{N}+\mathrm{S}(1,8-4,5 \%)$. Отношение $\mathrm{C} / \mathrm{H}$ составляет $7,4-8,4$, атомное $\mathrm{H} / \mathrm{C}-1,4-1,6$. Содержание масел в битумах находится в пределах $45-65 \%$ с явным преобладанием в их составе метаново-нафтеновых углеводородов (УВ) $(60-90 \%)$ над ароматическими $(10-40 \%)$, смол - 35-45\%, асфальтенов до $10 \%$. Исходя из приведенных показателей, эти битумы классифицируются как мальты (табл. 3,4$)$.

Характерно, что с мальтами ассоциируются более редко встречаемые

Таблица 3

Характеристика битумов разных классов Эстонии

\begin{tabular}{|c|c|c|c|c|c|c|c|c|}
\hline \multirow{2}{*}{$\begin{array}{l}\text { Классы } \\
\text { битума }\end{array}$} & \multicolumn{5}{|c|}{ Элементный состав, \% } & \multicolumn{3}{|c|}{ Групповой состав, \% } \\
\hline & C & $\mathrm{H}$ & $\mathrm{O}+\mathrm{N}+\mathrm{S}$ & $\mathrm{C} / \mathrm{H}$ & $\mathrm{H} / \mathrm{C}_{\mathrm{aT}}$ & Масла & Смолы & $\begin{array}{l}\text { Асфаль- } \\
\text { тены }\end{array}$ \\
\hline
\end{tabular}

Нефти $\quad 85,5-86,4 \quad 10,6-11,9 \quad 1,7-3,8 \quad 7,3-8,1 \quad 1,5-1,65 \quad 70-75 \quad 20-25 \quad 4-6$

Мальты $\quad 85-86,7 \quad 10,1-11,5 \quad 1,8-4,5 \quad 7,4-8,4 \quad 1,4-1,6 \quad 45-65 \quad 34-45$ до 10

Асфальты $81,5-83,3 \quad 8,9-9,7 \quad 7,3-9,3 \quad 8,4-9,2 \quad 1,29-1,43 \quad 40-45 \quad 42-47 \quad 11-18$

Асфаль-

титы

$84,6-88,0 \quad 8,7-9,5 \quad 3,5-6,5 \quad 9,5-10,0 \quad 1,2-1,25 \quad 3-17 \quad 20-45 \quad 45-80$

Таблица 4

Классификационная схема природных битумов

(Успенский и др., 1964; Радченко, Успенский, 1979; Клубов, 1983)

\begin{tabular}{l|c|c|c|c|c|c}
\hline \multirow{3}{*}{ Показатель } & \multicolumn{5}{|c}{ Классы } \\
\cline { 2 - 5 } & Нефти & Мальты & Асфальты & $\begin{array}{c}\text { Асфаль- } \\
\text { титы }\end{array}$ & Кериты & $\begin{array}{c}\text { Антраксо- } \\
\text { литы }\end{array}$ \\
\hline
\end{tabular}

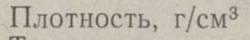

Твердость

(по Моосу)

Консистенция

Групповой состав, $\%$ :

масла

смолы

асфальтены

карбоиды

Растворимость

B $\mathrm{CHCl}_{3}$

Элементный состав, \%:

$\mathrm{C}$
$\mathrm{H}$
$\mathrm{O}+\mathrm{H}+\mathrm{S}$

$84-86$
$12,5-14,5$
$0,5-4,0$
$6-7,2$

$\begin{array}{ccc}0,75-0,96 & 0,95-1,05 & 1,0-1,12 \\ - & - & 0-1\end{array}$

жидкие высоковяз- твердые кие жидкие легкоплавкие

$\begin{array}{ccc}65-100 & 45-65 & 25-45 \\ 0-30 & 30-40 & 30-50 \\ 0-5 & 5-15 & 15-40 \\ 0 & 0 & 0 \\ \text { полная } & \text { полная } & \text { полная }\end{array}$

$1,05-1,3$

$2-3$

твердые хрупкие

твердые хрупкие

$1-2,5$

$1,3-2,0$

$2-4,5$ твердые хрупкие

138 
жидкие и твердые ПБ, причем в приповерхностной зоне и в трещинах чаще наблюдаются их твердые разности. Жидкие ПБ по элементному составу, согласно имеющимся данным, практически не отличаются от густых вязких мальт, за исключением разве что несколько повышенного атомного $\mathrm{H} / \mathrm{C}-1,5-1,65$ (табл. 3). В их компонентном составе отмечается более высокое содержание масел $(70-75 \%)$ и низкое асфальтенов $(4-6 \%)$. В составе масел преобладают метаново-нафтеновые УВ $(\sim 90 \%)$. Смолы и асфальтены в сумме составляют $25-30 \%$. По этим показателям жидкие битумы могут рассматриваться как высокосмолистые нефти. И. С. Гольдберг (1981) полагает, что граничащую с мальтами группу высокосмолистых нефтей правильнее будет относить к категории битумов, поскольку пространственно они совмещены с другими, более преобразованными разностями (мальтами, асфальтами), образуя с ними генетически единые зоны битумонакопления. Это в полной мере относится и к данному случаю.

В элементном составе твердых ПБ меньше С $(81,5-83,3 \%)$ и Н $(8,9-9,7 \%)$, но больше гетероэлементов: $\mathrm{O}-4,3-6,5 \%, \mathrm{~S}-1,8-4,4 \%$, $\mathrm{O}+\mathrm{S}+\mathrm{N}-7,3-9,3 \%$, а отношение $\mathrm{C} / \mathrm{H}-8,4-9,2$, атомное $\mathrm{H} / \mathrm{C}-$ $1,3-1,43$. Битумы содержат до $45 \%$ масел с примерно равным соотношением в них метаново-нафтеновых и ароматических УВ, смол - $42-47 \%$, асфальтенов и асфальтогеновых кислот - $11-18 \%$ (табл. 3). По существующим классификационным схемам твердые ПБ можно отнести к классу асфальтов (табл. 4).

Если рассматривать жидкие, вязкие и твердые ПБ Западной Эстонии в виде единого эволюционного ряда нефть-мальта-асфальт, то изменения в их элементном составе выражаются в уменьшении содержаний $\mathrm{C}, \mathrm{H}$, атомного $\mathrm{H} / \mathrm{C}$ и в увеличении содержания гетероэлементов и отношения С/H. В групповом их составе уменьшается содержание масляной фракции, а в ней - метаново-нафтеновых УВ и, соответственно, увеличивается доля смол и асфальтенов, а в маслах - доля ароматических УВ

Таким образом, выделенные по геолого-морфологическим особенностям и территориальномv расположению два типа битумопроявлений существенно различаются между собой и по вещественному составу битумов (табл. 3). Битумные «лепешки» север.-восточных районов Эстонии претерпели значительно бо́льшие изменения (до асфальтитов), они имеют более высокое содержание гетероэлементов, асфальтенов, выше отношение $\mathrm{C} / \mathrm{H}$ и ниже атомное $\mathrm{H} / \mathrm{C}$, нежели битумы западных районов. Деление их на классы по элементному и групповому составам довольно условное (рис. 2, 3). Фактически они представляют собой непрерывный ряд ассоциирующихся битумов - нефть-мальта-асфальт, имевших, можно полагать, единый источник миграции углеводородных флюидов. Возникшие различия в их составе можно объяснить разной степенью влияния процессов гипергенеза. Четких зависимостей в изменении свойств ПБ с глубиной их залегания не устанавливается, хотя, следует признать, все исследованные пробы битумов отобраны с небольшой территории, с близких и в целом небольших глубин - в основном от 0 до $100 \mathrm{~m}$.

Уменьшенная доля (менее 60\%) метаново-нафтеновых структур в маслах асфальтов (25-я и 26-я пробы) и мальт (24-я проба) свидетельствует скорее всего не столько о чисто химическом, сколько о биогенном окислении ПБ - биодеградации (Успенский и др., 1964; Гольдберг, 1981; Тиссо, Вельте, 1984). Касаясь источника битумов, можно предположить, что им могла быть нефть, мигрировавшая из погруженных частей Балтийской синеклизы, которая, как известно, вся, включая акваториальную часть, потенциально нефтеносна (Нефтяные месторождения Прибалтики, 1987). 
Приуроченность значительной части битумопроявлений $\mathrm{k}$ району Кярдлаской кратерообразной структуры можно, вероятно, объяснить тем, что в результате взрыва и образования локального поднятия увеличилась трещиноватость пород, сформировались зоны с повышенной проницаемостью, через которые мигрировали флюиды, улучшились коллекторские свойства толщи. Следует заметить, что в Северной Америке открыт ряд месторождений нефти (например, Вьюфилд) и газа (например, Лайс Ранч), связанных с астроблемами (Кучерук, 1989), где наибольшие скопления УВ приурочены, как и в нашем случае, к кольцеобразным краевым поднятиям импактных кратеров (Каттай, Клубов и др., 1990).

Не исключено, что процесс битумогенеза в районе Кярдлаской структуры был стимулирован энергией взрыва, как это произошло в окрестностях метеоритного кратера оз. Сильян в Швеции (Vlierboom и др., 1986). Шведские авторы связывают наличие большого количества проявлений битумов по периферии кратера с высокотемпературной возгонкой органического вещества ордовикских сланцев Третаспис.

Вопрос о происхождении асфальтитовых «лепешек», обнаруженных в восточных районах Эстонии, остается дискуссионным. Очевидно лишь, что источник их происхождения и условия формирования определенно были иными, чем битумов западных районов республики. Высказаны весьма противоречивые предположения о генетической связи указанных битумов с диктионемовыми сланцами (Doss, 1914), кукерситами (Коgerman, 1933; Клубов, Уров, 1988), шунгитами Карелии (Люткевич, Курбатская, 1984). Существует мнение и о бактериальном их происхождении (Пайс и др., 1979). Большинство исследователей склоняются к тому, что битумы образовались из сгустков закированной нефти и были привнесены в бассейн седиментации извне. В таком случае трудно определить источник, который мог бы периодически продуцировать битум в кембро-ордовикское время.

Таким образом, вопрос образования битумов на территории Эстонии в широком стратиграфическом диапазоне остается открытым, поскольку все высказанные идеи остаются на уровне предположений. Для его решения требуются обстоятельные и тонкие геохимические исследования.

\section{Л ИТЕ РА Т У Р А}

Гольдбере И. С. Природные битумы СССР (закономерности формирования и размещения). Л., 1981.

Ермакова Л. П., Синовский Г. В., Семенов С. С. Исследование состава и некоторых свойств асфальта, обнаруженного в шахте Кукрузе в Эстонском сланцевом бассейне // Сланцеперерабатывающее производство. Кохтла-Ярве, 1959, 41-43.

Kaттай B., Кала Э., Сууроя К. О распространении природных битумов на территории Әстонии // Изв. АН Эстонии. Геол., 1990, 39, № 3, 115-122.

Каттай В. А., Клубов Б. А., Кала Э. А., Сууроя К. А. О битумопроявлениях на острове Хийумаа // Горючие сланцы, 1990, 7, № 1, 10-18.

Каттай B. А., Кундель Х. А. Включения твердых битумов в кукерситах, состав и свойства этих битумов // Горючие сланцы, 1987, 4, № 1, 22-29.

Клубов Б. А. Природные битумы Севера. М., 1983.

Клубов Б. А., Уров К. Э. Вещественный состав и твердые битумы кукерского горизонта Прибалтийского сланцевого бассейна в свете новых данных // Горючие сланцы, 1988, 5, № $1,34-45$.

Кучерук Б. В. Астроблемы - новый перспективный объект для поисков нефти и газа // Геол. нефти и газа, 1989, № $11,57$.

Люткевич Е. М., Курбатская А. П. О генезисе асфальтитовых «лепешек» и «галек» нижнего кембрия и среднего ордовика Прибалтики // Геохим. сб., вып. 9. М., 1964, $101-111$.

Нефтяные месторождения Прибалтики. Вильнюс, 1987.

Паасикиви Л. Б., Закашанский М. С. Перспективы нефтеносности Прибалтики // Обзор ВИЭМС, вып. 34. М., 1965. 
Пайс Р., Клесмент И., Побуль Л. Углеводороды и кнслородные соединения в битумоиде сланца-кукерсита // Изв. АН ЭССР. Хим., 1979, 28, № 3, 182-190.

Радченко O. A., Успенский B. A. Генетические типы битумов и условия их образования // Закономерности формирования и размещения скоплений природных битумов. Л., $1979,32-51$.

Сакалаускас K. А. Тектоника и нефтегазоносность Юго-Западной Прибалтики. Вильнюс, 1968.

Tиссо Б., Вельте Д. Образование и распространение нефти. М., 1981.

Успенский B. A., Радченко О. А., Глебовская $E$. A. Основы генетической классификации битумов. Л., 1964.

Doss, B. Ein Vorkommen von Grahamit im Silurkalk bei Kunda in Estland // Zbl. Miner., $1914,609-615$.

Kogerman, $P$. The occurrence, nature and origin of asphaltites in limestone and oil shale deposits in Estonia // J. Inst. Petrol. Technol., 1933, 19, N 113, 215-222.

Müürisepp, $K$. Uhest uuest asfaltiidileiust Eestis // Eesti Loodus, 1962, nr. 5, 286-289.

Palmre, H. Maaõli tunnustest Paluküla kivimurrus Hiiumaal // ENSV TA Toim. Keem. Geol., 1967, 16, nr. 4, 344-345.

Vlierboom, F. M., Collini, B., Zumberge, J. E. The occurrence of petroleum in sedimentary rocks of the meteor impact crater at Lake Siljan, Sweden // Org. Geochem., $1986,10,153-161$.

Ннститут геологии

Академии маук Эстонии
Поступила в редакцию 18/XI 1989

\section{Vello KATTAI}

\section{EESTI LOODUSLIKE BITUUMENITE KOOSTIS}

Keemilis-bituminoloogiliste analüüside tulemused kinnitavad varem geoloogilis-morfoloogiliste tunnuste pöhjal tehtud oletust, et Eesti territooriumil esineb kaht tüüpi looduslike bituumenite ilminguid. Esimene tüüp: elemendilise ja grupilise koostise põhjal liigitatud madala kontsentratsiooniga (immutuslaigud või pooritäited) ning kõrgendatud tõrvasisaldusega naftad, maltad (valdavad) ja asfaldid. Teine tüüp: kõrge kontsentratsiooniastmega (lamedate läätsedena), koostiselt kuni asfaltiitideni moondunud looduslikud bituumeniilmingud, esinevad Kirde-Eestis. Nimetatud tüüpide tekketingimused ja aine algallikad on tõenäoliselt olnud erinevad. Nende täpsustamine nõuab detailseid geokeemilisi uuringuid.

\section{Vello KATTAI}

\section{COMPOSITION OF NATURAL BITUMENS IN ESTONIA}

The occurrence of two types of natural bitumens in Estonia, earlier suggested on the basis of geomorphic features, has been confirmed by the results of chemical analyses of bitumen. Considering the elemental and group composition we can distinguish (1) lowconcentration petroleum, maltha (predominating), and asphalt with a higher tar content, occurring as patches or pore filler, and (2) high-concentration natural bitumens with a changed composition (up to asphaltites), occurring as lenses in North-East Estonia. These types were evidently formed under different conditions and from different source materials, but detailed geochemical studies are required to ascertain this. 